\section{Commentary: Leading from the back}

\author{
Lawrence M. Wei, MD
}

In this issue of JTCVS Techniques, Bourdillon and colleagues ${ }^{1}$ present a unique case of robotic mitral valve repair in a patient with cardiac dextroversion. The case is notable because of the unusual anatomy, the method of repair, and use of the robotic approach.

The patient was a young woman with situs solitus and dextrocardia with moderate mitral regurgitation and systolic anterior motion causing severe left ventricular outflow tract (LVOT) obstruction. The authors clearly describe the embryology and pathoanatomy of this entity. Their analysis of this patient's valve revealed an elongated posterior leaflet and acute aorto-mitral angle, 2 factors that predispose to systolic anterior motion and LVOT obstruction. A minimally invasive, robotically assisted approach was chosen, but the rotation and displacement of the heart necessitated replacement of the standard right thoracic incisions by a left-sided approach. The authors expertly navigated a pectus deformity, anterior displacement of the phrenic nerve, and a left superior vena cava draining into a large coronary sinus, in addition to the inverted orientation of the mitral valve. Their method of repair was dictated by the complex anatomy and included posterior annuloplasty with a semirigid partial ring and closure of a cleft between P1 and P2. The ring implantation technique, previously described ${ }^{2}$ and employed routinely at the authors' institution, imbricated excessive posterior leaflet tissue, reducing its height and displacing

\footnotetext{
From the Department of Cardiovascular and Thoracic Surgery, West Virginia University, Morgantown, WVa.

Disclosures: The author reported no conflicts of interest.

The Journal policy requires editors and reviewers to disclose conflicts of interest and to decline handling or reviewing manuscripts for which they may have a conflict of interest. The editors and reviewers of this article have no conflicts of interest.

Received for publication Nov 12, 2021; revisions received Nov 12, 2021; accepted for publication Dec 2, 2021; available ahead of print Jan 11, 2022.

Address for reprints: Lawrence M. Wei, MD, Department of Cardiovascular and Thoracic Surgery, West Virginia University Heart and Vascular Institute, One Medical Center Dr, Morgantown, WV 26506 (E-mail: lawrence.wei@wvumedicine. org).

JTCVS Techniques 2022;11:19-20

2666-2507

Copyright (c) 2022 The Author(s). Published by Elsevier Inc. on behalf of The American Association for Thoracic Surgery. This is an open access article under the CC BY-NC-ND license (http://creativecommons.org/licenses/by-nc-nd/4.0/).

https://doi.org/10.1016/j.xjtc.2021.12.001
}

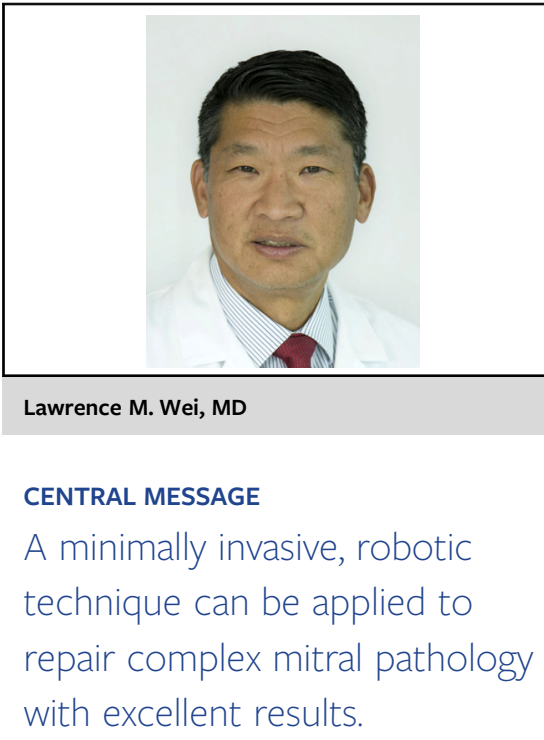

the coaptation plane from the LVOT. They achieved an excellent result, eliminating both the mitral regurgitation and LVOT obstruction.

Robotic mitral valve repair is safe, effective, durable, and cost-neutral compared with sternotomy. ${ }^{3}$ Excellent outcomes with low complication rates, fewer transfusions, shorter ventilation times, decreased intensive care unit and hospital stays, diminished postoperative pain, faster return to normal activity levels, and greater patient satisfaction have been reported. ${ }^{3-7}$ Although early robotic mitral surgeons carefully selected low-risk patients with simple pathology (mostly isolated posterior leaflet prolapse), experienced centers now apply robotic technology to a broad spectrum of patients with mitral disease, including older, greater-risk patients and those with more complex mitral pathology. ${ }^{5-8}$ Bileaflet disease, annular calcification, endocarditis, reoperations, combined procedures, and valve replacements all can be approached robotically. This report illustrates that in the hands of a well-trained team led by an accomplished mitral surgeon, robotic repair is a versatile technique that is adaptable to nearly any mitral valve pathology. The common leadership adage, popularized by Nelson Mandela, of "leading from the back while letting others believe they are in the front" has unique application here. Not only do front, back, and side take on a whole new meaning in this case, it illustrates that with good training, experience, and leadership of a robotic team, anything is possible. 


\section{References}

1. Bourdillon A, Elder R, Lalonde M, Steele J, Gruber PJ, Geirsson A. Robotic mitral valve repair in a patient with cardiac dextroversion. J Thorac Cardiovasc Surg Tech. 2022;11:12-6.

2. Hashim PW, Assi R, Hashim SW. The imbrication technique: an alternative to the sliding leaflet technique. Ann Thorac Surg. 2014;98:1124-6.

3. Coyan G, Wei LM, Althouse A, Roberts HG, Schauble D, Murashita T, et al. Robotic mitral valve operations by experienced surgeons are cost-neutral and durable at 1 year. J Thorac Cardiovasc Surg. 2018;156:1040-7.

4. Murphy DA, Moss E, Binongo J, Miller JS, Macheers SK, Sarin EL, et al. The expanding role of endoscopic robotics in mitral valve surgery: 1,257 consecutive procedures. Ann Thorac Surg. 2015;100:1675-81; discussion 1681-2.
5. Gillinov AM, Mihaljevic T, Javadikasgari J, Suri RM, Mick SL, Navia JL, et al. Early results of robotically assisted mitral valve surgery: analysis of the first 1000 cases. J Thorac Cardiovasc Surg. 2018;155:82-91.e2.

6. Mihaljevic T, Jarret CM, Gillinov AM, Williams SJ, DeVilliers PA, Stewart WJ, et al. Robotic repair of posterior mitral valve prolapse versus conventional approaches: potential realized. J Thorac Cardiovasc Surg. 2011;141:72-80. e1-4.

7. Ramzy D, Trento A, Cheng W, DeRobertis MA, De Robertis MA, Mirocha J, et al. Three hundred robotic-assisted mitral valve repairs: the Cedars-Sinai experience. $J$ Thorac Cardiovasc Surg. 2014;147:228-35.

8. Ranganath NK, Loulmet DF, Neragi-Miandoab S, Malas J, Spellman L, Galloway AC, et al. Robotic approach to mitral valve surgery in septo-octogenarians. Semin Thorac Cardiovasc Surg. 2020;32:712-7. 